\title{
TERAPI NON FARMAKOLOGI SEBAGAI BENTUK SWAMEDIKASI LANSIA DALAM MANAJEMEN NYERI OSTEOARTRITIS
}

\author{
NON-PHARMACOLOGICAL THERAPY: ELDERLY SWAMEDICATION IN \\ OSTEOARTHRITIS PAIN MANAGEMENT
}

\author{
Erwin Kurniasih $^{1}$, Endri Ekayamti ${ }^{2}$, Pariyem $^{3}$ \\ 1,2,3 Akademi Keperawatan Pemerintah Kabupaten Ngawi \\ Email Koresponden: yamti.endrieka@gmail.com
}

\begin{abstract}
ABSTRAK
Lansia merupakan masa dimana orang akan mengalami penurunan akibat proses menua (aging) yang ditandai oleh perubahan fisik maupun psikologis yang akan mempengaruhi fungsi dan kemampuan tubuh secara keseluruhan. Salah satu gangguan yang dirasakan adalah fungsi muskuloskeletal seperti nyeri sendi (osteoarthritis). Nyeri sendi pada lansia dapat diatasi secara farmakologi ataupun non farmakologi. Kegiatan pengabdian masyarakat ini bertujuan untuk memberdayakan kemampuan lansia dalam mengatasi permasalahan nyeri sendi melalui swamedikasi terapi non farmakologi. Metode yang digunakan adalah penyuluhan serta pelatihan terapi non farmakologi. Pelatihan terapi non farmakologi yang diberikan meliputi senam rematik dan pembuatan obat-obat tradisonal untuk mengatasi nyeri sendi pada lansia. Kegiatan diikuti oleh 43 peserta, kegiatan penyuluhan dan pelatihan dilaksanakan di posyandu lansia desa balongcapang yang didampingi oleh perawat koordinator dari puskesmas Pangkur, bidan desa, dan kader dari posyandu lansia Desa Balongcapang. Pelaksanaan evaluasi monitoring kegiatan dilakukan selama tujuh hari. Hasil kegiatan menunjukkan penyuluhan tatalaksana terapi nonfarmakologi dalam rangka menurunkan nyeri sendi sangat bermanfaat terhadap lansia, dibuktikan dengan antusiasnya peserta dalam mengikuti kegiatan mulai dari awal hingga akhir. Hasil evaluasi dari pelatihan senam rematik dan terapi herbal dengan kompres jahe sebagian besar lansia dapat mengikuti dan mempraktikkannya sendiri di rumah masing-masing, serta terbukti mampu mengurangi nyeri sendi yang dirasakan lansia.
\end{abstract}

Kata kunci: Terapi Nonfarmakologi, Lansia, Nyeri osteoartritis

\begin{abstract}
Elderly is a period where people will experience a decline due to the aging process which is characterized by physical and psychological changes that will affect the function and ability of the body as a whole. One of the perceived disorders is musculoskeletal function such as joint pain (osteoarthritis). Joint pain in the elderly can be treated pharmacologically or non-pharmacologically. This community service activity aims to empower the ability of the elderly to overcome joint pain problems through nonpharmacological therapy self-medication. The method used is counseling and non-pharmacological therapy training. The non-pharmacological therapy training provided includes rheumatic gymnastics and the manufacture of traditional medicines to treat joint pain in the elderly. Activity attended by 43 participants, counseling and training activities were carried out at the posyandu for the elderly in Balongcapang village, accompanied by a coordinating nurse from the Pangkur Health Center, a village midwife, and cadres from the Posyandu for the elderly in Balongcapang Village. The evaluation of activity monitoring was carried out for seven days. The results of the activity showed that nonpharmacological therapy management counseling in order to reduce joint pain was very beneficial for the elderly, as evidenced by the enthusiasm of participants in participating in activities from beginning to end. The results of the evaluation of rheumatic gymnastics training and herbal therapy with ginger compresses, most of the elderly can follow and practice it themselves in their respective homes, and are proven to be able to reduce joint pain felt by the elderly.
\end{abstract}

Keywords: Non-pharmacological therapy, the elderly, osteoarthritis pain 


\section{PENDAHULUAN}

Lanjut usia (lansia) adalah masa yang akan dialami semua orang, dimana orang akan mengalami penurunan berbagai fungsi tubuh akibat penuaan (aging) yang ditandai dengan perubahan fisik maupun psikologis sehingga kemampuan tubuh juga menurun. Secara fisik proses menua banyak terlihat dari beberapa penurunan fungsi organ dan sistem tubuh, hal ini akan mempengaruhi fungsi dan kemampuan tubuh secara keseluruhan. Selain itu perubahan dari kondisi fisik yang banyak dialami oleh lansia yaitu masalah pada fungsi muskuloskeletal yang menyebabkan terjadinya perubahan secara degeneratif yang dirasakan dengan keluhan nyeri sendi (Christensen, 2006).

Berbagai keluhan penyakit degeneratif yang banyak dilaporkan terjadi pada lansia adalah arthritis, hipertensi, gangguan pendengaran, kelainan jantung, sinusitis kronik, penurunan visus, dan gangguan pada tulang (Stanley, 2007). Salah satu golongan penyakit yang paling banyak dikeluhkan oleh lansia pada masalah muskuloskeletal adalah osteoartritis. Osteoartritis merupakan penyakit degeneratif pada kartilago sendi dengan perubahan reaktif pada batas-batas sendi (Ervan, 2011, Yuliastri 2012). Kejadian penyakit ini akan meningkat seiring dengan bertambahnya usia (Elvira 2010). Lansia dengan masalah osteoartritis akan memengaruhi mobilitas dan aktivitas yang merupakan masalah vital bagi kesehatan total lansia. Keluhan ini juga dapat berdampak pada penurunan kualitas hidup lansia.

Penyakit rematik yang paling banyak ditemukan pada golongan lansia di lndonesia, angka kejadian berkisar 50-60\% (Muchid dkk., 2006). Data dari World Health Organization (2011) menunjukkan jumlah penderita osteortritis di seluruh dunia sebanyak 151,4 juta jiwa. Pada kawasan Asia Tenggarakejadian osteortritis mencapai 24 juta jiwa (Arden \& Nevitt, 2006). Di Indonesia, prevalensi osteoarthritis mencapai $5 \%$ pada usia $<40$ tahun, 30\% pada usia 40-60 tahun, dan 65\% pada usia > 61 tahun (Bactiar, 2010). Hasil pengkajian yang dilakukan di Dusun
Balongcapang, Desa Pangkur, Ngawi di dapatkan dari 43 lansia $17 \quad(40 \%)$ diantaranya mengalami keluhan nyeri sendi. Arthritis dan gangguan pada tulang menyebabkan munculnya nyeri sendi. Nyeri sendi merupakan nyeri yang dirasakan di bagian persendian dan sekitarnya akibat proses inflmasi maupun terjadi secara idiopatik (Yatim, 2006). Banyaknya masyarakat khususnya lansia yang mengobati nyeri sendi dengan berbagai cara yang dianggap mampu mengatasi dan meringankan nyeri persendian. Hal ini menunjukan bahwa nyeri yang dirasakan akibat rematik sangat mengganggu dalam kehidupan lansia sehingga lansia susah dalam melakukan aktivitas. Disamping itu masih banyak pandangan masyarakat Indonesia yang menganggap remeh penyakit ini karena sifatnya seakan tidak menimbulkan ancaman jiwa, padahal rasa nyeri yag ditimbulkan akibat penyakit ini justru menjadi penghambat yang sangat menganggu bagi masyarakat untuk melakukan aktivitas sehari-hari (Handono,2000).

Lokasi osteoartritis yang sering ditemukan adalah pada lokasi lutut (Arissa, 2013). Lokasi terjadinya osteoartritis serupa dengan laporan data Riskesdas yang menyatakan bahwa lokasi terbanyak terjadinya adalah pada sendi lutut yang mencapai 89,91\% (Riskesdas, 2013). Adanya nyeri sendi yang adiakibatkan karena osteoartritis mengakibatkan lansia mengalami keterbatasan gerak pada area yang sakit. Jika aktivitas gerak sendi pada lansia pasif dan dominan pada bagian tertentu akan mengakibatkan kekakuan dan gangguan pada otot sendi (Isbagio, 2005). Nyeri dan kekakuan pada sendi secara terus menerus dan berlangsung lama akan membatasi aktiviats fisik lansia, selanjutnya lansia akan mangalami penurunan kualitas hidup (Hopman-Rock et al, 2007).

Tindakan pengobatan yang dapat dilakukan untuk mengurangi nyeri sendi akibat osteoertritis pada lansia bisa dengan terapi farmakologis dan non farmakologis. Secara farmakologis yaitu dengan tindakan pemberian obat-obatan, sedangkan tindakan nonfarmakologis antara lain seperti edukasi lansia, terapi fisik, okupasional, aplikasi 
dingan atau panas, latihan fisik, istirahat, dan merawat persendian, penurunan berat badan jika mengalami obesitas, dan akupuntur (Muchid, 2006).

Penelitian yang dilakukan oleh Masyhurrosyidi, dkk (2014) terhadap 20 orang dengan osteoartritis didapatkan hasil bahwa pemberian kompres hangat dengan rebusan jahe secara bermakna mampu menurunkan tingkat nyeri pada lansia. Ayu \& Warsiti (2012) dalam penelitiannya yang dilakukan pada 15 responden di dapatkan hasil bahwa dengan pelaksanaan senam lansia yang dilakukan pada pagi hari sebelum sarapan selama 15-45 menit sangat efektif mengatasi nyeri lutut pada lansia. Suherry, dkk (2014) dalam penelitiannya yang menggunakan olesan campuran daun pandan wangi dan virgin coconut oil (VCO) pada bagian sendi yang mengalami nyeri di dapatkan hasil bahwa secara signifikan dapat menurunkan nyeri sendi pada lansia dengan osteoartritis. Melihat banyaknya manfaat terapi non farmakologi terhadap penurunan nyeri osteoartristis, maka perlu diaplikasikan secara nyata sebagai bentuk pemberdayaan masyarakat.

\section{MASALAH}

Berdasarkan hasil survey yang dilakukan di Dusun Balongcapang Desa Pangkur Kabupaten Ngawi didapatkan jumlah lansia sebanyak 43 orang. Hasil pengkajian pada riwayat penyakit dengan memberikan kuesioner terhadap lansia ditemukan bahwa sebagian besar lansia menyatakan mengalami keluhan nyeri sendi. Keluhan nyeri sendi yang dirasakan lansia tersebut mengganggu aktivitas sehari-hari mereka sehingga, perlu dilakukan upaya pencegahan dan pengobatan untuk mengatasinya yang kemudian diharapkan lansia di Dusun Balongcapang mampu beraktivitas seharihari.

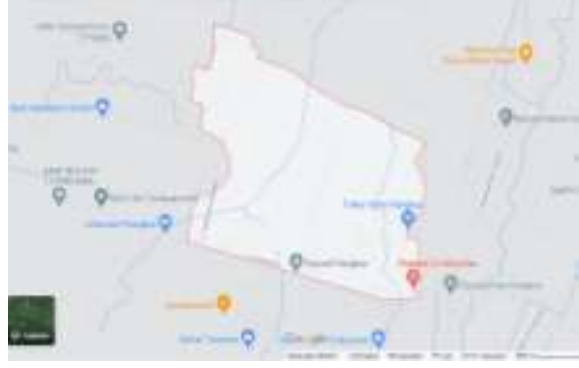

Gambar Lokasi Desa Pangkur, Kec. Pangkur Kab. Ngawi

\section{METODE}

Kegiatan pengabdian masyarakat ini dilakukan dengan melibatkan kader lansia, perawat koordinator wilayah kerja Puskesmas Pangkur, dan bidan desa balongcapang juga mahasiswa Akper Pemkab Ngawi. Polpulasi target yaitu warga lansia di Dusun Balongcapang, Desa Pangkur, Ngawi sejumlah 43 lansia. Pada populasi target dilakukan kegiatan seperti pemeriksaan kesehatan (tekanan darah, asam urat). Penyuluhan tentang penyakit osteoarthritis, mengajarkan beberapa alternative terapi non farmakologi untuk menurunkan nyeri sendi lansia, pelatihan pada lansia tentang senam rematik untuk menurunkan nyeri osteoarthritis, dengan metode kegiatan sebagai berikut:

\section{A. Tahap persiapan}

Tahap persiapan ini dilakukan penyebaran undangan dengan melibatkan mahasiswa, yang diberikan pada lansia dusun balongcapang Desa Pangkur. Undangan diberikan kepada kurang lebih 50 lansia. Penekanan untuk kesedian kehadiran dengan memberitahukan pada lansia bahwa akan ada pemerikasaan kesehatan gratis. Untuk lansia yang rumahnya jauh dari lokasi kegiatan dan tidak ada yang mengantar akan di lakukan penjemputan.

Persiapan lain yang dilakukan pada kegiatan ini meliputi: berkoordinasi dengan perangkat desa setempat seperti Lurah, Kasun, RT dan RW, serta kader yang nantinya bisa mensosialisasikan hasil dari kegiatan ini pada saat posyandu lansia. Persiapan sarana prasarana persiapan tempat, persiapan bahan pendukung kegiatan seperti LCD, layar proyektor, 
materi penyuluhan, liflet, sound sistem. Juga persiapan alat pelaksanaan tes kesehatan seperti: tensimeter dan stetoskop untuk mengukur tekanan darah, alat pengukuran gula darah, asam urat, stik, lanset dan alkohol swab.

\section{B. Tahap pelaksanaan}

Pelaksanaan kegiatan dimulai pada pukul 08.00 diawalai dengan melakukan pemeriksaan kesehatan pada lansia yang meliputi: pengukuran tekan darah, asam urat serta glukosa darah. Setelah pemeriksaan kesehatan selesai, lansia diberikan penyuluhan terkait dengan penyuluhan tentang penyakit osteoarthritis, mengajarkan beberapa alternative terapi non farmakologi untuk menurunkan nyeri sendi lansia. Media yang digunakan untuk penyuluhan menggunakan LCD proyektor dan beberapa contoh bahan herbal seperti jahe yang merupakan salah satu alternative bahan alternative untuk mengurangi nyeri sendi dimana penggunaanya dengan cara digeprek dan di kompres di area sendi yang sakit. Selanjutnya dilanjutkan mengajarkan senam rematik untuk menurunkan nyeri osteoarthritis, dengan memutar music dan diikuti oleh seluruh peserta.

Gambar 2. Pemerikasaan Kesehatan

\section{HASIL DAN PEMBAHASAN}

Kegiatan pengabdian masyarakat dalam rangka intervensi non farmakologi pada nyeri sendi lansia dihadiri oleh 43 warga dan dilaksakan di Posyandu lansia di Dusun Balongcapang, Desa Pangkur,

\section{Evaluasi}

Jumlah lansia yang hadir dalam kegiatan ini sejumlah 43 orang dari total lansia 50 orang di dusun balongcapang. Ketidakhadiran lansia ini disebabkan karena bertepatan dengan musim panen, sehingga lansia yang masih sehat dan aktif bekerja lebih memilih untuk panen padi ke sawah. Selain itu kegiatan juga dihadiri oleh kader dari puskesmas Pangkur, dan kader desa.

Pelaksanaan kegiatan ini kami mendapat dukungan penuh dari warga dusun Balongcapang terbukti dengan dukungan warga dalam memberikan fasilitas berupa tempat, juga antusiasme lansia yang tinggi terbukti dengan banyaknya pertanyaan yang diberikan lansia pada saat penyuluhan berlangsung. Secara keseluruhan dari kegiatan pengabdian masyarakat yang dilakukan di Desa Balongcapang Desa Pangkur Kecamatan Pangkur Kabupaten Ngawi, mulai dari pemerikasaan kesehatan, penyuluhan tatalaksana nyeri sendi pada lansia dan pelatihan senam rematik berlangsung dengan tertib dan lancar.

Ngawi. dari hasil pemeriksaan kesehatan didapatkan data warga yang mengalami nyeri pensedian (osteosrtritis) adalah sebagai berikut

Tabel 1. Hasil pemeriksaan kesehatan lansia di Dusun Balongcapang, Desa Pangkur, Ngawi sebelum dilakukan terapi non farmakologi.

\begin{tabular}{ccccccc}
\hline \multirow{2}{*}{ Usia (tahun) } & \multicolumn{2}{c}{ Tekanan darah } & \multicolumn{2}{c}{ Asam urat } & \multicolumn{2}{c}{ Nyeri sendi } \\
\cline { 2 - 7 } & $\mathbf{N}$ & $\mathbf{1 N}$ & $\mathbf{N}$ & $\mathbf{N}$ & $\mathbf{N y e r i}$ & Tidak nyeri \\
\hline $40-49$ & 3 & 2 & 3 & 2 & 1 & 4 \\
$50-59$ & 3 & 8 & 5 & 6 & 4 & 7 \\
$60-69$ & 5 & 13 & 8 & 10 & 6 & 12 \\
$\geq 70$ & 1 & 8 & 7 & 2 & 7 & 2 \\
Jumlah total & 12 & 31 & 19 & 24 & 18 & 25 \\
\hline
\end{tabular}

Hasil pengukuran tekanan darah dari tabel 1 sebelum diberikan terapi non farmakologi menujukkan dari 43 orang sebagian besar tekanan darahnya tidak normal (cenderung tinggi) yaitu sebanyak 31 orang $(72 \%)$ yang didominasi pada rentang usia 60-69 tahun yaitu 13 orang, sementara untuk usia rentang 40-49 tahun hanya 2 orang saja. Untuk nilai pengukuran kadar asam urat dengan nilai lebih dari 
normal ada 24 orang (55\%) yang sebagian besar berada di rentang usia 60-69 tahun yaitu 10 orang sedangkan yang paling sedikit di rentang usia $\geq 70$ tahun dan usia 40-49 tahun yaitu 2 orang. Sementara itu dari 43 orang, masalah nyeri sendi dialami oleh 18 orang ( $42 \%$ ) dimana sebagian besar berada pada kelompok usia $\geq 70$ tahun yaitu sebanyak 7 orang dan paling sedikit pada kelompok usia 40-49 tahun sebanyak 1 orang.

Tabel 2. Hasil pemeriksaan kesehatan lansia di Dusun Balongcapang, Desa Pangkur, Ngawi setelah dilakukan terapi non farmakologi.

\begin{tabular}{ccccccc}
\hline \multirow{2}{*}{ Usia (tahun) } & \multicolumn{2}{c}{ Tekanan darah } & \multicolumn{2}{c}{ Asam urat } & \multicolumn{2}{c}{ Nyeri sendi } \\
\cline { 2 - 7 } & $\mathbf{N}$ & $\mathbf{\neq N}$ & $\mathbf{N}$ & $\mathbf{N}$ & Nyeri & $\begin{array}{c}\text { Tidak } \\
\text { nyeri }\end{array}$ \\
\cline { 2 - 7 } $40-49$ & 3 & 2 & 3 & 2 & 1 & 4 \\
$50-59$ & 4 & 7 & 7 & 4 & 3 & 8 \\
$60-69$ & 7 & 11 & 8 & 10 & 3 & 15 \\
$\geq 70$ & 1 & 8 & 7 & 2 & 6 & 3 \\
Jumlah total & 15 & 28 & 19 & 24 & 13 & 30 \\
\hline
\end{tabular}

Setelah dilakukan pelatihan terapi non farmakologi yang meliputi senam rematik, pijat refleksi, teknik kompres pada nyeri sendi serta teknik pemilihan makanan sehat didapatkan hasil seperti pada tabel 2 diatas. Hasil menujukkan adanya perubahan tekanan darah pada kelompok usia 50-59 tahun yaitu meningkat dari $3(27 \%)$ orang menjadi $4(36 \%)$ orang dan pada kelompok usia 60-69 tahun sebanyak 2 orang dari 5 (28\%) menjadi 7 (39\%) dengan nilai tekanan darah normal. Nilai pemeriksaan untuk asam urat normal ada peningkatan sebanyak 2 orang pada kelompok usia 5059 tahun yaitu dari $5(45 \%)$ orang menjadi $7(63 \%)$ orang. Sementara itu, kondisi nyeri sendi terlihat paling signifikan perubahannya setelah diajarkan terapi non farmakologi. Terdapat tiga kelompok rentang usia yang mengalami penurunan nyeri atau menjadi tidak nyeri setelah melakukan terapi mandiri. Dari kelompok usia 50-59 tahun terlihat penambahan 1 orang yang tidak nyeri

Adanya perubahan tekanan darah menjadi normal bisa terjadi akibat efek pijat refleksi yang rutin dilakukan. Tarigan (2009) menjelaskan bahwa terapi pijat refleksi menjadi salah satu cara yang efektif untuk menurunkan tekanan darah. Hal ini dikarenakan pijat reflesi dapat memperlancar aliran darah sehingga memberikan efek relaksasi, menjadikan kondisi tubuh seimbang dari 7 (63\%) orang menjadi 8 (72\%). Untuk kelompok usia 60-
69 tahun terdapat penambahan 3 orang yang tidak mengalami (penurunan) nyeri sendi yaitu dari 12 (66\%) orang menjadi 15 $(83 \%)$ orang. Kelompok terakhir pada kelompok $\geq 70$ tahun ada penambahan 1 orang yang derajat nyerinya mengalami penurunan yaitu dari $2(22 \%)$ orang menjadi 3 (33\%) orang. Uma, 2006 dalam Rezky, 2015). Adanya pijat refleksi dapat menurunkan kadar kortisol sebagai hormon pemicu sumber stress dan depresi yang dapat menurunkan efek penurunan tekanan sistolik dan diastolik sehingga fungsi tubuh semakin membaik (Nugroho, 2012).

Diit yang sehat juga memberikan pengaruh pada penurunan tekanan darah pada penderita hipertensi. Diit rendah natrium dinilai cukup efektif dalam menurunkan tekanan darah pada penderita hipertensi. Hal ini sesuai dengan penelitian dari Muliyawati, dkk (2014) yang menjelaskan bahwa orang dengan asupan natrium berlebih 5,6 kali lebih berisiko mengalami hipertensi dibandingkan orang yang asupan natriumnya rendah karena natrium yang berlebih dalam tubuh dapat meningkatkan volume plasma, curah jantung, dan tekanan darah. Tekanan darah yang tidak turun setelah dilakukan terapi non farmakologi bisa dipengaruhi oleh penurunan hormon estrogen pada wanita setelah menopause. Estrogen menjadi salah satu hormon yang berfungsi meningkatkan kadar HDL yang berperan dalam menjaga kesehatan pembuluh darah. Penurunan 
kadar estrogen saat menopause akan diikuti dengan penurunan HDl yang bisa menjadi faktor risiko hipertensi bila tidak diikuti dengan gaya hidup yang sehat (Sari dan Susanti, 2016).

Adanya nilai asam urat yang tinggi sangat dipengaruhi oleh faktor gaya hidup terutama dari asupan. Beberapa jenis makanan tinggi purin seperti sayuran (bayam, tomat, kacang-kacangan), daging dan ikan serta minuman manis dapat memicu peningkatan asam urat yang termanifestasi pada rasa nyeri di persendian. Asupan makanan yang tidak seimbang dengan kadar purin terlalu tinggi dapat memicu terjadinya penumpukan urin di persendian sehingga menyebabkan penyakit gout (Utami, 2009). Hasil pemeriksaan menunjukkan bahwa kelompok usia yang lebih tua (60-69 tahun) memiliki prevalensi yang lebih tinggi untuk mengalami penyakit gout. Hal ini dikarenakan semakin bertambah usia jika asupan protein banyak maka semakin menambah timbunan purin dalam darah yang menyebabkan penyakit gout (Sholihah, 2014). Setelah dilakukan pelatihan terapi non farmakologi terlihat adanya penambahan lansia dengan nilai asam urat normal yang bisa dipengaruhi peningkatan pengetahuan setelah penyuluhan sehingga bisa memilih makanan yang tepat dengan kadar purin rendah.

Nyeri sendi pada lansia bisa disebabkan oleh berbagai faktor seperti osteoartritis (radang sendi), rheumatoid artritis (penyakit rematik), obesitas, maupun penyakit gout (asam urat). Prevalensi nyeri sendi lebih tinggi pada kelompok usia lanjut akibat penipisan dan pengeroposan tulang rawan (cartilago articular) sehingga mudah terjadi peradangan (Corwin, 2009). Hasil evaluasi pelatihan terapi non farmakologi pada lansia menunjukkan adanya penurunan nyeri pada sejumlah lansia. Ini bisa terjadi karena aplikasi senam rematik secara rutin. Senam rematik terbukti dapat meningkatkan pengeluaran hormon endorphin yang berperan dalam memblokir substansi substansi p dari neuron sensorik sehingga proses transmisi impuls nyeri di medulla spinalis menjadi terhambat dan sensasi nyeri akan menurun (Price and Wilson, 2005 dalam Sitinjak, dkk., 2016). Melakukan kompres hangat secara rutin memberikan efek terhadap penurunan nyeri sendi. Hal ini dikarenakan kompres hangat pada permukaan tubuh dapat memperbaiki fleksibilitas tendon dan ligament, mengurangi spasme otot, meredakan nyeri, meningkatkan aliran darah dan metabolism (Kozier and Erb's, 2009 dalam Sinaga, 2015). Kompres hangat yang sederhana dan mudah dilakukan adalah dengan bahan herbal seperti jahe. Jahe merupakan tanaman yang mudah didapat apalagi bagi lansia yang tinggal didesa. Pemberiannya sengat mudah yaitu satu ruas jahe ditumbuk kemudian dioleskan pada bagian yang mengalami nyeri, dan diamkan beberapa saat.

\section{KESIMPULAN}

Kegiatan penyuluhan serta pelatihan seperti senam rematik dan pemberian kompres hangat sebagai tatalaksana terapi nonfarmakalogi terbukti efektif mampu menurunkan nyeri sendi pada lansia. Dengan penyuluhan pengetahuan lansia menaingkat dan dengan pelatihan senam rematik lansia mampu secara mandiri untuk mempraktikkannya sendiri dirumah. Kompres hangat yang diberikan pada bagian sendi seperti salah satunya dengan jahe yang digeprek juga sangat sederhana dan mudah untuk diaplikasikan pada lansia.

\section{DAFTAR PUSTAKA}

Arissa, M.I. (2013). Pola distribusi kasus osteoarthritis di RSU Dokter Soedarso Pontianak periode 1 Januari 2008 - 31 Desember 2009. Jurnal Mahasiswa PSPD FK Universitas Tanjungpura, 1(1), h.1-16. Badan Pusat Statistik Indonesia. (2015). https://www.bps.go.id/. diakses tanggal 1 Maret 2019

Ayu, A.D. Warsito, B. E. (2012). Pemberian Intervensi Senam Lansia Pada Lansia Dengan Nyeri Lutut. Jurnal Nursing Studies. Volume 1. Nomor 1 Tahun 2012. Halaman 60 - 65 
s1.undip.ac.id/index.php/jnursing

http://ejournal-

Bachtiar, A. (2010). Pengaruh Ekstrak Jahe (Zingiber Officinale) terhadap Tanda dan

Gejala Osteoarthritis pada Pasien Rawat Jalan di Puskesmas Pandan Wangi Kota Malang. Tesis FIK UI, 1 87.

Corwin, EJ. (2009). Buku Saku Patofisiologi Ed. 3. Jakarta: Buku Kedokteran EGC.

Elvira. (2010). Osteoarthtis Genu. http://www.diskdr-online. com/news/5/OSTEOARTHRITISGENU. 2010. diakses tanggal 4 Maret 2019

Hopman-Rock, Kraaimaat, M.F.W., \& Bijlsma, J.W.J. (2013). Quality of life in

elderly subjects with pain in the hip or knee. Quality of Life Research, 6(1), p.67-76.

Isbagio, H. (2005). Pendekatan diagnostik penyakit rematik. Subbagian Reumatologi.

Bagian Ilmu Penyakit Dalam Fakultas Kedokteran Universitas Indonesia/ Rumah

Sakit Dr. Cipto Mangunkusumo. Jakarta: Cermin Dunia Kedokteran, hal.12-26.

Masyhurrosyidi. H., Kumboyono, Utami, Y. W. (2014). Pengaruh Kompres Hangat Rebusan Jahe Terhadap Tingkat Nyeri Subakut dan Kronis pada Lanjut Usia dengan Osteoarthtritis Lutut di Puskesmas Arjuna Kecamatan Klojen Malang Jawa Timur. Majalah Kesehatan FKUB. Volume 1, Nomer 1, Maret 2014. Hal 39-44

Muchid, dkk. (2006). Pharmaceutical care untuk pasien dengan penyait arthritis rematik. Direktorat Bina Farmasi Komunitas dan Klinik Ditjen Bina Kefarmasian dan Alat Kesehatan Dinas Kesehatan.

Muliyawati, dkk. (2011). Hubungan Pola Konsumsi Natrium Dan Kalium Serta Aktifitas Fisik Dengan Kejadian Hipertensi Pada Pasien Rawat Jalan Di Rsup Dr. Wahidin Sudirohusodo Makassar. Media Gizi Masyarakat
Indonesia, Vol.1,No.1,Agustus 2011 : 46-51

Nugroho, I. A., Asrin, dan Sarwono. (2012, Juni). Efektivitas pijat refleksi kaki dan hipnoterapi terhadap penurunan tekanan darah pada pasien hipertensi. Jurnal Ilmiah Kesehatan Keperawatan, $8(2)$.

Rezky, dkk. (2015). Pengaruh Terapi Pijat Refleksi Kaki Terhadap Tekanan Darah Pada Penderita Hipertensi Primer. JOM Vol. 2 No. 2, Hal. 1454-1462.

Sari dan Susanti. (2016). Hubungan Jenis Kelamin Dengan Kejadian Hipertensi Pada Lansia Di Puskesmas Nglegok Kabupaten Blitar. Jurnal Ners dan Kebidanan, Volume 3, Nomor 3, Desember.

Sinaga. (2015). Pengaruh Kompres Hangat Pada Nyeri Sendi Lansia (60-74 tahun). Prosiding Seminar Ilmiah Nasional Keperawatan. $3^{\text {rd }}$ Adult Nursing Practice: Using Evidence in Care.

Sitinjak, dkk. (2016). Pengaruh Senam Rematik terhadap Perubahan Skala Nyeri pada Lanjut Usia dengan Osteoarthritis Lutut. Jurnal Keperawatan. Volume 4 Nomor 2 Agustus 2016.

Stanley, M. (2007). Buku ajar keperawatan gerontik (Gerontological nursing: A health promotion or protection approach). Jakarta: EGC

Suherry, R., Ah Yusuf, Indarwati, R. (2014). Pemberian Campuran Daun Pandan Wangi (Pandanus Amaryllifolius Roxb) dan Virgin Coconut Oil (VCO) Berpengaruh Terhadap Penurunan Nyeri Sendi Pada Lansia Dengan Osteoartritis. Jurnal Ners Unair. Hal 99-105

Tarigan. (2009). Sehat dengan terapi pijat. Diakses pada tanggal 24 April 2019 dari http://www.mediaindonesia.com.

Yatim F. (2006). Penyakit tulang dan persendian (artritis atau artralgia), Edisi.

1.

Jakarta: Pustaka Populer Obor. h. 2632, 111- 115 .

Yuliastari. Aminurul. (2012). Pengaruh Kompres Panas dengan Kompres Dingin 
Terhadap Pengurangan Nyeri pada Osteoarthritis Sendi Lutut. Naskah Publikasi. Fakultas Ilmu Kesehatan
Universiats

Muhammadiyah

Surakarta. Surakarta.2012. 